\title{
HARIDUSKRIIS NÕUKOGUDE EESTIS
}

\author{
Väino SIRK
}

Tallinna Ülikooli Ajaloo Instituut, Rüütli 6, 10130 Tallinn, Eesti; vsirk@hot.ee

20. sajandi hariduslugu iseloomustab paradoksaalsus ja vastuolulisus. Hariduse arengut jälgiti vaimustuse, ühtlasi nõutuse ja isegi hirmuga nii Esimeses, Teises kui ka Kolmandas Maailmas. Oma ajastu produkt oli ka Nõukogude impeeriumi haridussüsteem, mille väikeseks koostisosaks oli Eesti NSV haridussüsteem. Esialgu puuduvad meil viimasest põhjapanevad ajaloolised uurimused. Artiklis on püütud seni saavutatut koondada ning arendada, rakendades nii Läänes kui Idas kasutatud hariduskriisi mõistet, ja hõlmata haridusloolisse töösse Eesti sotsioloogide ning majandusteadlaste (Jelena Helemäe, Ellu Saare, Väino Rajangu jt) huvitavaid uurimistulemusi. Nõukogude aja suursaavutuseks, samuti sotsiaalse õigluse väljenduseks peeti eriti kesk- ja kõrghariduse ulatuslikku laienemist 1920.-1930. aastatega võrreldes. Sellise apologeetika reministsentse kandub inertsi mõjul ka taasiseseisvumise järgsesse aega. Autori üheks sihiks on näidata, et ehkki haridussüsteemi laienemine on demokraatlik suundumus, ei taga see automaatselt nimetatud süsteemi demokraatlikkust.

1968. aastal avaldati Oxfordi Ülikooli Kirjastuse poolt Rahvusvahelise Hariduse Arendusnõukogu strateegiliste uuringute direktori (Vice-Chairman and Director of Strategy Studies of the International Council for Educational Development) Philip H. Coombsi raamat "The World Educational Crisis", mis ilmus peagi ka venekeelses tõlkes (märkusega tiitlil: teaduslike raamatukogude jaoks). Loomulikult pidi nõukogude teadus teesi ülemaailmsest hariduskriisist kindlalt tagasi lükkama ja seda tehtigi toimetusepoolses saatesõnas: sotsialistlikes maades ei saavat juttugi olla hariduse kriisist - raskused ja vastuolud lahendatakse seal plaanipäraselt riigi tegevuse kaudu. ${ }^{1}$

P. H. Coombs väidab, et 1950. aastate algul hakkas haridus kogu maailmas arenema sellises tempos, millist inimkonna varasem ajalugu ei tundnud. Ometi suurenes kirjaoskamatute arv maailma täiskasvanud elanikkonna hulgas. Üldine kriis ei väljendunud vaid selles, et paljudes maades ja piirkondades puudusid koolimajad ning õpetajad ja lapsed jäid täiesti hariduseta. Niisugused nähtused iseloomustasid peamiselt vaesemaid maid, kolooniaid või mõne areneva riigi mahajäänud piirkondi. Tööstusriikide probleemid olid valdavalt teistsugused. Neid iseloomustati sõnadega kiire muutumine, kohandumine ja lõhe. Üldiselt kohandub haridus-

${ }^{1}$ Кумбс Ф. Г. Кризис образования в современном мире. Системный анализ. Москва, 1970, 3. 
süsteem jõudsalt muutuva keskkonna ja teadmiste ning info plahvatusliku kasvuga aeglaselt ja hilinemisega. Nii tekib lõhe hariduse ning ühiskonna tegelike elutingimuste ja vajaduste vahel. Haridussüsteemi üheks omaduseks on inertsus. Inimeste soov haridust omandada võib ületada hariduse saamiseks reaalselt olemasolevad võimalused (vahendite nappus). Sotsiaalne nõudlus hariduse järele kipub kasvama kiiremini kui ühiskonna kvalifitseeritud töötajate vajadus. Haridusel on omadus kasvatada vajadust hariduse järele, arenenud maades avaldus see eelkõige kõrg-, osalt ka keskhariduse vallas, sest algharidus oli juba aastakümneid kõigile kättesaadav olnud.

Aastate möödudes avaldas P. H. Coombs oma teose täiendatud, ajas edasi viidud variandi. Ta väidab, et 1970. aastatel ja järgmise kümnendi algul on ülemaailmne hariduskriis jätkunud ja omandanud isegi uusi dimensioone, millest tähtsaim on usalduskriis hariduse kui niisuguse suhtes üldse. ${ }^{2}$

Mõistet kriis võib tõlgendada erinevalt. Võib-olla sellepärast ei kasuta kõik maailma hariduslugu käsitlevad autorid Coombsile iseloomulikku pikale veniva ülemaailmse hariduskriisi mõistet. Kuid kõik tõsised uurijad märkavad hariduse edukäigu ja tagasilöökide vaheldumist globaalses ulatuses, 20. sajandi haridusprotsessi paradoksaalsust, mida ometi saab erineval viisil interpreteerida. ${ }^{3}$ Hariduse tähtsus tõuseb, ühtlasi teravnevad probleemid temas ja tema ümber.

Hariduse andmine saavutas enneolematu ulatuse, samas selgus, et hariduse kättesaadavust määravad sotsiaalsed tegurid püsivad ja avaldavad visalt oma konservatiivset mõju. On öeldud, et isegi 20. sajandi viimasel kümnendil olid erineva sotsiaalse tagapõhjaga lastel hariduse saamise võimalused sama ebavõrdsed kui sajandi algul. ${ }^{4}$

Nõukogude režiimi süvenevad vastuolud, kõikehõlmav üldkriis, agoonia ja kollaps on üldtuntud tõsiasjad. Põhjendatult võib rääkida ka nõukogude hariduskorralduse kriisist, sest totalitaarne süsteem hoiab haridust oma tugevas haardes. Nõukogude Liitu vaadeldi hariduse kontekstis tavaliselt kui tööstusmaad. Lisaksin, et Nõukogude Liidus segunes nii tööstusriigile kui arengumaale iseloomulikke kriisinähtusi.

Tundub, et hariduslugu ja -sotsioloogia pööravad liialt vähe tähelepanu asjaolule, et 20. sajand oli mitte ainult vabanemise, vaid ka koloniaalse rõhumise, vallutuste ja rahvaste hävitamise sajand. Needki jooned kajastusid Nõukogude Liidu hariduspoliitikas. Balti riigid olid impeeriumis okupeeritu ja annekteeritu seisundis. Okupeeritud maa haridus on aga alati kriisiseisundis nagu ikestatud rahva enesetunnetuski.

Teise maailmasõja alguseks oli Eesti Vabariigi haridussüsteem muutumise ja edasiarendamise faasis. Siinkohal saab meenutada vaid mõningaid fakte 1930. aastate keskpaigas ja teisel poolel tehtust. Üldhariduskooli õppeaega pikendati 11 aastalt 12-le, nagu see oli tollal enamikus Euroopa riikides, USA-s, Kanadas ja

2 Coombs, P. H. The World Crisis in Education. The View from the Eighties. New York; Oxford, Oxford University Press, 1985, 9.

3 Aldrich, R. (koost). A Century of Education. London; New York, Routledge/Falmer, 2002, 229.

4 Aldrich, R. A Century of Education, 229. 
Jaapanis. ${ }^{5}$ 1937. aastal jagati kutsekoolid alamasse, kesk- ja kõrgemasse astmesse. Kutsehariduse arengut ühtlutati ja seostati paremini üld- ning kõrgharidusega. Eesti sai ka teise ülikooli, kui 1936. aastal teadusliku tehnikakõrgkoolina asutatud Tallinna Tehnikainstituut nimetati 1. jaanuarist 1938 ümber Tallinna Tehnikaülikooliks.

\section{OKUPATSIOON JA KOOLI ARENG 1958. AASTANI}

Hariduskorraldus ei olnud muidugi täiusele jõudnud ja lõplikult välja kujunenud, kui Eesti Vabariik inkorporeeriti 1940. aastal NSV Liitu, kus ei oldud veel jõutud üldise kirjaoskuseni (1930. aastal oli kirjaoskajaid 62,6\%) ja kehtis demokraatlikest Läänemaadest tunduvalt erinev koolikorraldus. Valitses riiklik koolisüsteem, keskharidus oli suhteliselt lühema (10 aastat) kursusega ja koolikohustus piirdus maal nelja aastaga (üldine 7-klassiline koolikohustus kehtestati NSV Liidus 1949. aastal). Eesmärgiks seati sarnastada Eesti kool NSV Liidu omaga, kuid esialgu säilis erijooni. Erakoolid reorganiseeriti riiklikeks või suleti, positiivne oli koolikohustuse pikendamine 14. eluaastalt 15. eluaastani. Kõik koolitüübid jäid algul Eesti NSV Hariduse Rahvakomissariaadi alluvusse. Keskharidust andnud progümnaasium, reaalkool ja gümnaasium asendati ühtse keskkooliga. Paljudes 6-klassilistes algkoolides avati VII klass. Õppekavast arvati välja usuõpetus, kodanikuõpetus ja vanad keeled, oluliseks aineks sai vene keel. Õpetus pidi lähtuma marksismi-leninismi seisukohtadest, mis olid ainuõiged, vaieldamatud ja tulid muuta õpilaste veendumusteks. Tegemist oli dressuurikooliga, kus maailmavaateline tõde oli iseenesestmõistetavalt teada, seda otsida ei olnud tarvis ega lubatavgi. Paljudes koolides moodustati komnoorte ja pioneeride allorganisatsioonid.

Teadlased on rõhutanud hariduselu kasvavat politiseerimist 1940. aastate algusest ja hariduse kui individuaalse väärtuse, inimisiksuse kujundaja ning eesmärgi iseeneses tagaplaanile langemist 20. sajandi teise poole realismi ja utilitarismi hindavas maailmas. ${ }^{6}$ Kommunistlik (nagu ka fašistlik) süsteem paistis selles suhtes silma küünilise vägivaldsusega, seades eesmärgiks uue inimtüübi kujundamise. Hariduskorraldust ja õppetöö sisu muudeti õpetajate ähvardamise, vallandamise ja arreteerimise toel. Ehkki õpilaste vastupanu rahvusliku hariduse lammutamisele polnud vägivaldne, suruti see karmilt maha. Siseasjade Rahvakomissariaadi töötajad tungisid juba 1940. aasta sügisel koolidesse, korraldasid ülekuulamisi ja vahistasid õpilasi otse kooliruumides. ${ }^{7}$ Esimesel Nõukogude okupatsiooni aastal kaotas Eesti õpetajaskond $10-13 \%$ oma koosseisust. ${ }^{8}$ Vägivalda eskaleeriti sammsammult, saavutades kulminatsiooni 1941. aasta kevad- ja suvekuudel. Baltimaade hariduselus alates suvest 1940 toimunut võib nimetada teiseks vallutuseks, nagu

\footnotetext{
5 Rannap, H. 1930. aastate keskkoolireformist. - Haridus, 1993, 10, 47.

${ }^{6}$ Halls, W. D. Contemporary History of Education. - The International Encyclopedia of Education. Second Edition. Volume 3. Toim T. Husén, T. Neville Postlethwaite. Pergamon, 1994, 1063.

7 Andresen Rauale 26.10.1940. Eesti Riigiarhiivi Filiaal (ERAF), f 1, n 1, s 262, 11.

8 Ant, J. Eesti 1939-1941: rahvast, valitsemisest, saatusest. Tallinn, 1999, 144.
} 
vägivalda oma rahva teadvuse kallal on nimetanud Aasia ja Aafrika koloniaalrahvaste esindajad. Vallutatud rahvaste vaimne rõhumine, kasutades selleks ka haridussüsteemi, ja okupeeritute hingelised kannatused moodustasid kindlasti ühe tahu 20. sajandi teise poole ülemaailmses hariduskriisis, mida aga paljud autorid ei näi märkavatki.

Saksa okupatsiooni ajal lähtuti koolikorralduses mõneti Eesti Vabariigi pärandist, ilmnesid aga konservatiivsed ja limiteerivad tendentsid. Koolisüsteemi hakati kujundama osalt elulähedasemaks (pragmaatilisemaks), osalt elitaarsemaks. Eesmärgiks seati piirata gümnaasiumiklasside ja -lõpetajate arvu, suunata õpilasi kutsekooli ja ühtlasi elustada klassikalist haridust. ${ }^{9}$ Ilmnes püüd kujundada tulevikus taas maskuliinsem haritlaskond.

Taasokupeerimise järel Eestisse jäänud kõrgharitlaste arvu on hinnatud vaid paarile tuhandele. ${ }^{10}$ 1934. aasta rahvaloenduse järgi oli Eestis 7437 kõrgharidusega inimest. 1944/45. õppeaastal suudeti Eesti koolid enamasti avada, suund võeti 7-klassilisele koolikohustusele. Diferentseeritud õpetamine keskkoolides kadus, kõik koolid töötasid ühtse õppeplaani alusel. ${ }^{11}$ Taas algas Eesti kooli sovetiseerimine. 1940. aastate keskel ja teisel poolel esines Eestis arengumaade hariduskriisile iseloomulikke nähtusi: laste alatoitlus, riiete nappus, kasutamiskõlblike koolihoonete vähesus ja õpikute ning vihikute puudumine. Pikkamööda sellised kriisitunnused suuremas osas elimineeriti, kuid püsisid ebakindlus ja hirm, mis kümnendi lõpul isegi süvenesid. Vabariikliku alluvusega linnade ja rajoonide haridusosakondadele allutati 30-40, paiguti üle 50 kooli, mis jaotati inspektorite vahel. ${ }^{12}$ Kontroll kooli üle oli tihedam kui tsaariaegsel venestusajal või Eesti Vabariigis.

1930. aastate lõpuks oli Eesti üldhariduskoolide õpetajaskond võrdlemisi hea ettevalmistusega. 1938/39. õppeaastal moodustasid kutseta õpetajad vaid 2,4\% algkooliõpetajate üldarvust, keskooliõpetajatest oli 1935/36. õppeaastal kutsega 90,3\% (nn vanades keskkoolides). Uutes gümnaasiumides oli 1938/39. õppeaasta algul 10,2\% kutseta õpetajaid. ${ }^{13}$ Võõrvõimude vägivald ja põgenemine Läände tõi sõja lõpukuudeks kaasa tõelise pedagoogilise kaadri kriisi, mis oli Esimese maailmasõja järgsest teravam ja kestvam. Ahto Kenniku järgi oli kutseta õpetajate protsent 1945/46. õppeaastal vähemalt 45. Sellal oli Eesti üldhariduskoolide põhikohaga õpetajatest (kokku 5 308) kõrgharidusega 9,2\%, pedagoogilise haridusega $45,8 \%$, üldkeskharidusega $31,2 \%$ ja lõpetamata keskharidusega $13,8 \% .{ }^{14}$ Kesk-

9 Nagel, V. Haridusest ja hariduspoliitikast Saksa okupatsiooni ajal Eestis. - Forseliuse Sõnumid, 2003, 10, 53.

10 Helemäe, J., Saar, E., Vöörmann, R. Kas haridusse tasus investeerida? Hariduse selekteerivast ja stratifitseerivast rollist kahe põlvkonna kogemuste alusel. Tallinn, 2000, 193.

11 Kits, A. Üldhariduskoolid Eesti NSV linnades aastail 1944-1946. - Nõukogude Kool, 1989, 11,41 .

12 Schneider, H., Tamm, I. Kohalike nõukogude haldusaparaadi täiustamise võimalused. - Eesti Kommunist, 1970, 9, 32.

13 Karjahärm, T., Sirk, V. Vaim ja võim. Eesti haritlaskond 1917-1940. Tallinn, 2001, 91, 97, 99.

14 Kennik, A. Õpetajate ettevalmistamine Eesti NSV-s sõjajärgsel taastamise ja sotsialismi ülesehitamise ajajärgul (1944-1965). - 300 aastat pedagoogikaharidust Eestis. Konverentsi ettekanded. Tallinn, 1984, 63. 
kooliklasside (VIII-XI) õpetajatest oli veel 1956/57. õppeaastal vaid 69,9\% kõrgharidusega. ${ }^{15}$ Õpetajate palk ei olnud Nõukogude Liidus kõrge, kuid suhteliselt madal oli see peaaegu kõikjal Euroopas. Turumajanduslikes riikides tõstis õpetajatöö mainet selle ameti püsikindlus, sõltumatus majanduse tõusudest või seisakutest, kindel palk, teatav sotsiaalne prestiiž, pikk suvepuhkus jne. ${ }^{16}$ Nõukogude õpetaja oli paljude Läänemaade kolleegidega võrreldes majanduslikult ja moraalselt surutud olukorras ja tugeva järelevalve ning ühiskondlike kohustuste koorma all. See vähendas elukutse prestiiži, kuid ei teinud seda ometi nulliks.

\section{AASTA KOOLIREFORM: TOOTMISÕPETUST EI SAADA EDU}

Kuni 1958. aastani kehtis Eestis 7-klassiline koolikohustus, mida 1950. aastate esimesest poolest alates suudeti üldjoontes täita. See oli kahtlemata positiivne saavutus. Põhihariduse omandanute arv ületas 1960. aastate algul isegi 15-aastaste arvu. See näitab, et paljud varem sündinud omandasid põhihariduse töö kõrvalt. ${ }^{17}$

Teadus- ja tehnikarevolutsiooniga kaasnes kõigi arenevate riikide sotsiaalses struktuuris vaimse töö tegijate osatähtsuse kasv. Ameerika Ühendriikides oli haridus juba 1950. aastatel muutunud inimtegevuse üheks kõige kesksemaks haruks. ${ }^{18}$ Üsna väikese hilinemisega jõudsid samasugusesse staadiumi Lääne-Euroopa arenenud riigid. Ometi ilmnes mittevastavus antava hariduse ja ühiskonna eluliste vajaduste vahel. Nõukogude teoreetikud, nagu öeldud, eitasid hariduskriisi omal maal, tegelikult juhtkond adus, et muutused on vajalikud.

Nõukogude Liit püüdis juba selgelt ilmnevat mahajäämust ületada hariduse kvantitatiivset külge edendades (üleminek 8-aastasele kooliharidusele, keskhariduse saamise võimaluste laiendamine jne), mis kahtlemata oli positiivne. Keskhariduse omandanute arv kasvas 1950. aastate lõpul ja järgmise kümnendi algul pidevalt, sh tänu kaugõppele. Keskkoolilõpetamine tähendas sel ajal ikka veel kuulumist põlvkonna haritumasse ossa. Üldhariduskeskkool oli siis orienteeritud peamiselt kõrgkooliastujate ettevalmistamisele. Olukord muutus, kui 1960. aastate teisel poolel võeti kurss massilisele keskharidusele. ${ }^{19}$ Hariduse kvaliteedi parandamine osutus aga problemaatilisemaks. Selles osas takerduti traditsioonilisse sotsialistide-kommunistide haridusideoloogiasse, puudu jäi innovatiivsusest. Nii keskkui kõrgkooli püüti ümber korraldada põhimõttel ühendada õppimine tootliku tööga.

15 Eesti NSV rahvamajandus. Statistiline kogumik. Tallinn, 1957, 234-237.

16 Wall, W. D. Education and Mental Health. UNESCO, 1964, 254, 255, 261.

17 Helemäe, J., Saar, E. Eesti haridussüsteem 20. sajandi teisel poolel: kohortide võimalused ja valikud. - Eesti inimarengu aruanne 1999, 85.

18 Кумбс Ф. Г. Кризис образования в современном мире, 29.

19 Helemäe, J., Saar, E. Eesti haridussüsteem 20. sajandi teisel poolel: kohortide võimalused ja valikud, 86. 
Seda nõuti NLKP XX kongressil (1956). 1958. aasta 24. detsembril võttis NSV Liidu Ülemnõukogu vastu seaduse "Kooli ja elu sidemete tugevdamisest ja haridussüsteemi edasiarendamisest NSV Liidus", millele 24. aprillil 1959 järgnes vastav Eesti NSV seadus. ${ }^{20}$ Keskkooli peaülesandeks ei peetud enam teadmiste andmist kõrgkoolis õppimiseks, vaid noorte ettevalmistamist elluastumiseks. 1958. aasta üleliidulise koolireformiga pikendati üldharidust 10 aastalt 11 aastale, sest palju aega kulus nüüd tööalaseks õppeks ja lihtsalt tasuta või naeruväärse hüvitisega tööks. Eesti koolidele (11 aastat) aga lisa-aastat ei antud. Töö ja õppimise seostamine öeldi iseenesest tagavat õppetöö viljakuse kasvu. Laiendati õhtu- ja kaugõppekoolide võrku: nende arv tõusis 64-lt 1959/60. õppeaastal 119-le 1965/66. õppeaastal. Kehtestati üldine 8-klassiline koolikohustus, millele üleminekut alustati 1959/60. õppeaastast (üleminek loeti lõppenuks 1962/63. õppeaastal, mil anti esimesed 8-klassilise kooli tunnistused, kuid veel 1977. aastal lõpetas 8-klassilise kooli normaalajaga $92 \%$ sinna astunuist). ${ }^{21}$

Keskkooli IX-XI klassi õppeplaani viidi 10-12 nädalatunniga tootmisõpetus: teoreetiline ja praktiline väljaõpe mingil kutsealal koos tööga tootmisettevõttes. Nii loodeti lahendada üldharidusliku, polütehnilise ja kutsealase ettevalmistuse probleem nende harmoonilise ühendamise teel. ${ }^{22}$ Tootmisõpetus lõppes kohustusliku kvalifikatsioonieksamiga. Seega iseloomustas tootmisõpetust kitsalt kutsealane suund. Kuna puudusid vastav õppepersonal ja õppebaasid, ei suudetud täisväärtuslikku kutseharidust anda. Oskamata kutseharidust noortele ligitõmbavaks muuta, devalveeriti üldhariduslikku keskkooli, mis ei olnud enam ei tõeliselt üldhariv ega ka tõeline kutseõppeasutus. Mööndi küll, et keskkoolis ei pea olema peaeesmärgiks kutseala, vaid polütehnilise baasi andmine, mille alusel on hiljem võimalik omandada mis tahes eriala. Samas rõhutati, et valitud erialal tuleks omandada ikkagi vähemalt kõige madalam kvalifikatsioon. Paratamatult tekkis aga vastuolu: keskharidusega noor sattus töökollektiivis kõige elementaarsemale tööle ja suhtumine temasse oli vastav. Puuduliku üldharidusega töölistest, kel oli kõrgem kvalifikatsioon, peeti hoopis enam lugu. Sageli nägid ettevõtete ja majandite juhid keskkoolinoortes lihtsalt abitööjõudu. ${ }^{23}$ Töökasvatust pidi tugevdama ka õpilaste iseteenindamine (näiteks klassiruumide koristamine). Eesmärgiks seati kollektiivis toimuva ühiskondliku kasvatuse tõhustamine. Teiste õppeainete (eriti humanitaarainete) osakaal keskkoolis vähenes ja noorte üldhariduslik ettevalmistus kõrgkoolis õppimiseks langes. Kannatasid emakeeleõpetus, üldkultuuriline ja esteetiline külg. Teisel üleliidulisel kunstnike kongressil tõdes Eesti esindaja Jaan Jensen, et

20 Eesti Nõukogude Sotsialistliku Vabariigi seadus kooli ja elu sidemete tugevdamisest ning haridussüsteemi edasiarendamisest Eesti NSV-s. - Eesti NSV Teataja, 4. juuni 1959, nr 31, art 164, $1085-1102$.

21 Nõukogude Eesti. Entsüklopeediline teatmeteos. Teine, täiendatud trükk. Tallinn, 1978, 170.

22 Türnpuu, L. Töökasvatuse olukord koolis olgu parteiallorganisatsiooni tähelepanu keskpunktis. - Koolide parteiorganisatsioonide töökogemusi. Artiklite kogumik. Koost G. Sarri. Tallinn, 1963, 169.

23 Türnpuu, L. Töökasvatuse olukord koolis olgu parteiallorganisatsiooni tähelepanu keskpunktis, 169. 
esteetiline kasvatustöö on üldhariduskoolis äärmiselt ebarahuldav ja keskkoolide vanemate klasside õpilaste teadmised kunstist on väga ebamäärased. ${ }^{24}$ Keskkooli alavääristamist sümboliseeris selle kinnitamine vastavate baasettevõtete juurde.

\section{ÜHTNE ÜLDHARIDUSKOOL OSUTUB FIKTSIOONIKS}

1962/63. õppeaastast hakati üldhariduskooli lõpuklassis õpetama ühiskonnaõpetust, tugevdamaks ideoloogilist kasvatust. Eesti keele õpetus koondati ühte põhikontsentrisse V-VIII klassis, mis mõjus emakeele omandamisele negatiivselt. Vene keele õpetamisel pandi pearõhk kõnekeelele. Et mõnes koolis lubati teatud aineid süvendatult õpetada, tekkisid 1960. aastate keskel nn erikallakuga klassid (süvaõppeklassid) ja koolid täppisteaduste, võõrkeele, ajaloo, kunsti, muusika jne alal. Õppeplaani arvati vabalt valitavaid aineid (fakultatiivained). Nõukogude hariduspoliitika jäi fakultatiivainete ja eri-(süva)klasside lubamisest hoolimata üldiselt nivelleerivaks. Oli iseloomulik, et võimalust luua osale noortest täiendavaid arenguvõimalusi kasutati eriti usinalt Eestis. 1976. aastal oli 76\% Eesti koole, kus õpetati fakultatiivaineid (NSV Liidus keskmiselt 39\%). ${ }^{25} 1983$. aastal oli Eesti üldharidusliku keskkooli lõpetajatest süvaklassides õppinud ligikaudu kuuendik. ${ }^{26}$ Need klassid kujunesid intelligentsi taastootmise ülioluliseks baasiks. Sisuliselt tähendas see elitaarse keskhariduse võimaldamist osale, eriti suurte linnade noortele, tekitades nii kahtlemata haridusdemokraatia seisukohalt probleemi, oli aga siiski märk püüdest pöörata tähelepanu andekatele lastele. Talente toetav ja arendav haridus oli selleks ajaks Läänes, eriti USA-s juba üldlevinud nähtus. Üleliiduliste juhtnööride alusel lubati vabariigil koostada oma õppeplaane ja -programme. Alates 1960. aastatest muutus Eesti kooli ja hariduse mõningane erinemine Nõukogude Liidu taustast taas märgatavamaks. Osalt saavutati see oma eripära ja erivajadusi rõhutades, osalt eksperimenteerimise sildi all. ${ }^{27}$ Teatud liberaliseerimise ning vabariigi piiratud iseotsustamise poliitika pidurdamisest ja unifitseerimise tugevdamisest andis tunnistust NSV Liidu Haridusministeeriumi asutamine 1966. aastal, misjärel Eesti NSV Haridusministeerium degradeeriti liidulis-vabariiklikuks.

Teise maailmasõja järel oli eestlaste osakaal Eestis üle $97 \%$ ja peaaegu kogu haridussüsteem oli eestikeelne. 1956/57. õppeaastal oli 77\% Eesti üldhariduskoolidest eesti õppekeelega. 1972. aastaks langes eesti õppekeelega koolide osatähtsus 73\%-le. Koole, kus kasutati eesti ja vene õppekeelt, oli nii 1956/57. õppeaastal kui 1972. aastal $8 \%{ }^{28}$ Sisserändu soodustav poliitika viis eestlaste osakaalu rahvasti-

24 Loome rahvale. Eesti NSV Kunstnike Liidu juhatuse esimehe sm J. Jenseni sõnavõtt teisel üleliidulisel kunstnike kongressil. - Sirp ja Vasar, 19. apr, 1963, nr 16.

25 Eisen, F. Kakskümmend aastat Tõnismäel. - Looming, 1991, 7, 968.

26 Haridus. - Eesti inimarengu aruanne 1996, 18.

27 Sarv, E.-S. Demokraatiast ja humanismist õpetajale. Eesti haridusuuendus - demokratiseerimine ja humaniseerimine. Tallinn, 1997, 10.

28 Eesti NSV rahvamajandus. Tallinn, 1957, 228. 
kus kiirele langemisele (1989. aastal 61,5\%) ja venekeelne haridussektor laienes, ulatudes 1980. aastate algul üldhariduses ligi $1 / 3-$ ni. $^{29}$ Kolooniatele iseloomulikult ei toimunud Nõukogude okupatsiooni ajal ka Eestis sisserändajate märkimisväärset sulamist kohaliku rahva hulka. Vene õppekeelega koolides kasutati Vene NFSV õppeprogramme, teadliku poliitika tulemusena oli nendel koolidel nõrk side Eesti maa ning kultuuriga ja eesti keele õpetus oli ebaefektiivne või puudus üldse. Keelelt ja sisult dualistlik haridus kujundas kaks selgelt erinevat kogukonda, mida lahutasid keele- ja kultuuribarjäärid. Sotsiaalse kriisi süvenedes ähvardas kogukondade vastastikune võõristus kasvada avalikuks etniliseks konfliktiks. Eestlastest kasutasid vähesed võimalust saada venekeelset haridust - peamiselt Venemaa eestlased ja osalt Siberist naasnud küüditatud. Ent sisserännanute enamik, sh mitte ainult venelased, vaid ka ukrainlased, valgevenelased jt, ei soovinudki muud kui venekeelset kooliharidust. ${ }^{30}$ Sulaaja hariduspoliitika üheks näiliselt liberaalseks jooneks oli mäng vene keele vabatahtlikkuse ümber. Tegelikult otsiti võimalust ühiskondliku mõttevahetuse ja lastevanemate abiga rahvuskeelset haridust piirata. $^{31}$

\section{STAGNATSIOON}

1964/65. õppeaastast vähendati tootmisõpetuse tundide arvu ja loobuti kohustuslikust kvalifikatsioonieksamist. Tootmisõpetus asendus polütehnilise tööõpetusega, mille tähtsust järk-järgult kasvatati (1977. aastast süvendatud tööõpetus). 1978. aastal avati esimesed õppe-tootmiskombinaadid (1985. aastal oli neid 10). Vene õppekeelega koolid, mis seoses tootmisõpetusega olid muudetud 11-klassiliseks, viidi taas üle 10-aastasele kursusele. Seda taheti teha ka eestikeelse kooliga, kuid kultuuriavalikkuse toel õnnestus säilitada eestikeelne kool 11-klassilisena. ${ }^{32}$ 10-aastase eestikeelse üldhariduse kaitsjate üheks põhiargumendiks oli: 11 klassi tähendaks, et rahvamajandus saaks 4000 töötajat aastas hiljem. Seega tuleks kooliharidust kärpida valitseva tööjõunappuse tõttu. ${ }^{33}$ Hoopis vastupidi oli olukord arenenud Lääneriikides. Seal oli oluline, et kõrgharidussüsteem absorbeeris üliõpilaste näol märgatava osa tööjõust. ${ }^{34}$ Haridussüsteemi kärpimine võinuks põhjustada raskeid tööpuuduse või ületootmise probleeme.

29 1. oktoobril 1991 oli Eesti üldhariduskoolides 216965 õpilast, kellest vene keeles õppis 79691 (36,7\%) ja eesti keeles 137274 õpilast (63,3\%). - Eesti inimarengu aruanne 1996, 20.

30 Kirch, A., Kirch, M. Eesti ja vene õpetajate kultuurihuvidest ja rahvushoiakutest. - Nõukogude Kool, 1989, 10, 9.

31 Vt lähemalt Smith, J. Republican Authority and Krushchev's Education Reform in Estonia and Latvia 1958-1959. - The Sovietization of the Baltic States, 1940-1956. Toim O. Mertelsmann. Tartu, 2003, 237-252; Policy of Occupation Powers in Latvia 1939-1991. A collection of documents. State Archives of Latvia. Nordik, 1999, 450.

32 Hint, A., Merilaas, K., Kross, J., Maasik, E., Rummo, P., Vaidlo, R. Kas 10 või 11 klassi. Sirp ja Vasar, 12. märts 1965, nr 11.

33 Eisen, F. Kakskümmend aastat Tõnismäel, 961.

34 Collins, R. The Credential Society. An Historical Sociology of Education and Stratification. New York; San Francisco; London, Academic Press, 1979, 194-195. 
1960. aastate keskel hakati maal väiksemaid koole sulgema, linnas õppijate osakaal kasvas 1965/66. õppeaastal 71\%-ni õpilaste koguarvust. Sellega kaasnes maarahva koondumine keskustesse, talude tühjenemine ja noorte jätkuv võõrdumine maaelust. ${ }^{35}$ Maa-algkoolide likvideerimise ja reorganiseerimise kampaania oli Eestis intensiivsem kui Nõukogude Liidus tervikuna. Eestis jäi alles vähem kui 100 maa-algkooli, Leedus ligi 1 000, Lätis vaid $18 .{ }^{36}$ 1980. aastate esimesest poolest hakati mõnel pool asutama lasteaedu-algkoole, et haridussüsteemi esimesed lülid oleksid elukohale lähemal.

Keskkoolilõpetajate valikuvabadust püüti mitmel viisil kärpida. 1960. aastal piirati vastuvõttu kõrgkoolidesse ja keskeriõppeasutustesse. Eesmärk oli juhtida keskkoolilõpetanuid noorte hulgas ebapopulaarsetele tööaladele ehituses ja põllumajanduses. P. H. Coombsi järgi kulutati Nõukogude Liidus 1960. aastatel rahvuslikust tulust ja rahvuslikust koguproduktist haridusele umbes sama suur osa kui USA-s ja kõige hariduslembelisemates Lääne-Euroopa maades. ${ }^{37}$ Et aga Nõukogude Liidu rahvuslik tulu ja koguprodukt olid suhteliselt tagasihoidlikud, seadis juba finantseerimine hariduse arengule kitsamad piirid. 1940. aastatel ei edestanud USA NSV Liitu hariduskulude dünaamikas veel kuigivõrd. 1960. aastateks oli erinevus silmanähtav. Järgmistel kümnenditel kasvas hariduse finantseerimine NSV Liidus üsna ühetaolises, mõõdukas tempos, USA hariduskulude kõver otse sööstis kõrgusse. ${ }^{38}$ Aastal 1985 eraldati USA-s haridusele 244,4 miljardit dollarit, NSV Liidus vaid 38,4 miljardit rubla. Isegi otsearvestuse puhul ( 1 dollar $=1$ rubla $)$ oleks erinevus 6,4-kordne. Seejuures eraldati õppeasutustele riigieelarvest raha liiduvabariigiti ebavõrdselt, Eestile NSV Liidu keskmisest vähemgi. Aastail 1970-1989 oli Eesti hariduskulude reaalväärtus kasvanud vaid $6 \%$, mis oli ilmne stagnatsioon nii arenenud kui paljude arengumaade taustal. Riigieelarve kuludest üldhariduskoolidele eraldatud suhteline osa vähenes: $1970-4,7 \%, 1980-4,2 \%, 1985-3,7 \%$, 1988 - 4,3\%. Hariduskulude osa majanduse koguproduktis hindas majandusteadlane Ülo Tartu 1984. aastal 4,2\%-le. Aafrikas oli see juba kaks aastat varem olnud 5,2\%. Kriis majanduses võimendas kriisi hariduses. ${ }^{39}$

\section{AGRESSIIVNE KEELEPOLIITIKA JA 1984. AASTA REFORM}

Üldise majandusolukorra halvenemise taustal tugevdati ideoloogilist survet, lähtudes rahvuste ühtseks nõukogude rahvaks sulatamise teooriast. Tegelikkuses tähendas see 1970. aastate lõpust uusi vene keele õpetamise tõhustamise katseid,

35 Karmin, L. Muutused makoolide võrgus 1960.-1970. aastatel. - Nõukogude Kool, 1989, 12, 48-52.

36 Puhkim, H. Mõnedest sõjajärgse Eesti hariduselu keerdkäikudest. Eesti ühiskonna arengu sotsiaalsed ja õiguslikud aspektid. - Tallinna Tehnikaülikooli Toimetised, 1993, 735, 52.

37 Кумбс Ф. Г. Кризис образования в современном мире, 67.

38 Mikkal, V., Tartu, Ü. IME. Tehniline kõrgharidus - olukord ja arenguprobleemid. - Tehnika ja Tootmine, 1990, 1, 8, joon.

39 Tartu, Ü. Kui palju on parasjagu. - Haridus, 1990, 11, 10. 
kakskeelsuse ning vene keele kui teise emakeele jutlustamist ja emakeele ning võõrkeelte õpetamise osatähtsuse vähendamist. 1981. aastal hakati vene keelt Eesti koolis õpetama esimesest õppeaastast, vene keele õpetamist alustati ka lasteaias. Allutatud rahvaste reageerimises seesugusele survele on palju sarnasust. "Eestlastega saab siin lähemalt suhelda vaid see, kes oskab nende keelt või vähemalt avaldab selgesti oma lugupidamist selle vastu. Inimene, kes elab aastaid Eestis ja on lugupidamatu eesti keele ja kultuuri vastu, solvab sel kombel tahes või tahtmata, teades või teadmata eestlaste inimväärikust. Suhtumine eesti keelde on üks sõlmküsimusi eestlaste ja teiste rahvusrühmade vahekordade kujundamisel Eestis. /.../ Eestlaste ebakindlust tuleviku suhtes on põhjustanud /.../ ajalooõpetuses esinev venelaste osa eriline rõhutamine teiste rahvuste arvel," kirjutasid 40 eesti haritlast oma avalikus kirjas 28. oktoobril $1980 .^{40}$ Neidsamu mõtteid, kuid tunduvalt temperamentsemalt väljendas 1981. aastal Rahvaste Ühendusse võetud endise koloonia Antigua ja Barbuda elanik: "Ma kohtusin maailmaga läbi Inglismaa, ja kui maailm oleks tahtnud kohata mind, pidanuks ta tegema seda läbi Inglismaa. /.../ Te armastasite teadmisi ja kuhu te vaid läksite, te ehitasite kooli ja raamatukogu (jah, kuid neis mõlemas te moonutasite ja räsisite minu ajalugu ja ülistasite oma ajalugu)." ${ }^{.41}$ Ka Nõukogude haridusideoloogia taotles omal viisil valgustatud isiksust, kuid mingil juhul ei aktsepteerinud opositsiooniliselt mõtlevat isiksust.

Üldine keskharidus oli pikemat aega NLKP koolialaste eesmärkide hulgas. XX kongress andis direktiivi üldisele keskharidusele ülemineku kohta. XXII kongressil (1961) vastu võetud partei programmis oli see koos noorsoo kommunistliku kasvatamise ja isiksuse harmoonilise arendamisega haridusalaseks põhiülesandeks. Üldist keskharidust püüti tegelikkusesse rakendada eriti 1970. aastatel NLKP KK vastava otsuse (1972) alusel. NLKP XXVI kongressil (1981) kuulutati üleminek üldisele keskharidusele lõpetatuks, selle täielik teostamine osutus siiski ebareaalseks. Saavutused olid ikkagi hinnatavad: impeerium oli selles valdkonnas püüdnud sammu pidada maailma enam arenenud riikidega. Paraku tugevnesid peagi tagasikiskuvad tendentsid.

1984. aastal jõustati üldharidus- ja kutsekoolireform, parandamaks kutsesuunitlust ja tööks ettevalmistust. Olemuselt tähendas see paljuski tagasipöördumist kakskümmend aastat varem hüljatud tootmisõpetuse juurde. Eesmärk oli üld- ning kutsehariduse integratsioon ja üleminek üldisele kutseharidusele. Taheti luua üldja kutseharidust andev koolitüüp, mis tegelikult tähendanuks oskustööliste ettevalmistamist. Uuesti kinnitati koolidele baasettevõtted. Samas oli selge, et töökasvatuse efektiivsus on väike, kui selleks puudub ajakohane varustatus.

Koolireformis avaldus skeptiline suhtumine haritusse ja takerdumine majanduse ekstensiivarengu ideoloogiasse. Üldhariduskeskkooli ja kutsekooli ühtesulatamist ei jõutud lõpule viia, sest 1988. aastal kaotas see suund taas aktuaalsuse. Tööõpetus ja elukutsegi andmine keskkoolis ei olnud esmaavastus, seda tehti

40 Ajalehtedele Pravda, Rahva Hääl ja Sovetskaja Estonia. Avalik kiri Eesti NSV-st: Kiin, S., Ruutsoo, R., Tarand, A. 40 kirja lugu. Tallinn, 1990, 4-6.

41 The Post-Colonial Studies Reader. Toim B. Ashcroft, G. Griffiths, H. Tiffin. London; New York, Routlegde, 94. 
teisteski riikides. Küsimus oli pigem selles, et NSV Liidus ei suudetud tõhusa üldhariduse andmist ja ajakohast, arenenud tehnoloogial põhinevat kutseõpet ühendada. Selle üheks põhjuseks oli ka Nõukogude keskkooli suhteliselt lühike õppeaeg. Sisuliselt oli aastatel 1958-1964 ja 1984-1988 Eestis tegemist õpilaste monotehnilise tööõpetusega, ehkki nõukogude koolis oli loosungiks polütehniline õpetus. Tegelikult püüti õpilastele selgeks teha üks kitsas tööliseriala. ${ }^{42}$ Hariduskriisi 1984. aasta reform ei leevendanud, pigem süvendas seda.

\section{KUTSEHARIDUS JA MÜÜT HARIDUSE KÕIGILE KÄTTESAADAVUSEST}

Kutseõppeasutusi hakati juba 1940/41. õppeaastal NSV Liidu eeskujul viima Eesti NSV Hariduse RK alluvusest teiste ametkondade alluvusse. Nii lõhuti Eesti Vabariigi aegne haridussüsteemi administratiivne ühtsus. Alavääristati kutseõppeasutuste harivat osa ja kutsehariduse prestiiž langes. Ühtlasi kajastus selles töö väärtuse devalvatsioon töötajate riigis. Tuhandetele noortele tähendas kutsekooli suunamine üldharidustee liiga varast ja jäädavat lõppu.

Sõja järel koolisüsteemi hajutamine jätkus. Tehnikume anti Eesti NSV Haridusministeeriumi alluvusest teistele ministeeriumidele (enamik 1951. aasta märtsis). Haridusministeeriumile jäid vaid pedagoogilised õppeasutused. 1957. aastal allutati enamik tööstuslikest tehnikumidest Eesti NSV Rahvamajanduse Nõukogule. Nõukogude võim ajas majandusõppeasutuste - kaubandus- ja kommertskoolide, kodumajanduskoolide jt - sulgemise poliitikat. Neil koolidel oli olnud 20. sajandi esimesel poolel Eesti haridussüsteemis tähtis koht. Vaid mõni üksik neist kujundati ümber tehnikumiks.

1987. aastal valmistati Eesti keskeriõppeasutustes spetsialiste ette umbes 110 erialal. Nõukogude haridussüsteemi üheks puuduseks peeti keskerihariduse liiga tagasihoidlikku osatähtsust, mis põhjustas kõrgharidusega inimeste tööjõu ebaotstarbekat raiskamist lihtsamatele ja trafaretsetele tööülesannetele. Eestis oli aga tehnikumide võrk teiste vabariikidega võrreldes paremini välja arendatud ja keskerihariduse osatähtsus haridussüsteemis kui tervikus suhteliselt olulisem. ${ }^{43}$ Kutseja keskerihariduskoolid olid aga korraldatud tööstuse ekstensiivarengu ja põllumajandusliku suurtootmise vajadustest lähtudes, pealegi toodi neisse osa õpilasi ja õpetajaid Venemaalt jm. Aastail 1959-1969 arenes kõrgharitlaste ettevalmistamine Nõukogude Liidus kiiremini kui keskeriharidusega spetsialistide koolitamine. 1970. aastatel aga oli ennaktempo märgatav keskerihariduse vallas. Eestis oli viimase kasv üleliidulisest keskmisest kiiremgi. ${ }^{44}$

Kutsehariduse korraldus oli vastuolus üldise keskhariduse ideoloogiaga, seepärast hakati 1960. aastate lõpul asutama kutsekeskkoole. Aastail 1984-1985 muu-

42 Puhkim, H. Mõnedest sõjajärgse Eesti hariduselu keerdkäikudest, 51.

43 Mereste, U., Root, A. Rahvastik loenduspeeglis. 1989. aasta rahvaloendusest ja loendusandmete kasutamisest. Tallinn, 1988, 278.

44 Laas, K. Tööjõud NSV Liidus. Tallinn, 1982, 37-38. 
deti tehnikakoolid ja linna- ning maakutsekoolid kutsekeskkoolideks. Nii püüti kiiremini lahendada üldisele keskharidusele jõudmise ülesannet ja mõnevõrra ühtlustada noorema põlvkonna haridustaset. Paraku osutusid need püüdlused formaalseteks. Keskharidus üldhariduskeskkoolis ja kutsekeskkoolis esindasid erinevat kvaliteeti. See mõjutas nende koolide õpilaste kõrgkooli edasipääsemise võimalusi. Tegelikult kujunesid kutsekeskkoolid tupikkoolideks, ehkki formaalselt oli neis õppinutele tee kõrgkooli lahti. ${ }^{45}$ Nii kärbiti madalama haridustasemega vanemate, sageli tööliste lastel, kes põhikooli järel arvukalt kutsekoolidesse astusid, juba õppeasutuse valikuga eeldusi sotsiaalseks tõusuks, sest sotsiaalne seisund omandati Nõukogude ajal enamjaolt kindlat tüüpi hariduse kaudu. ${ }^{46}$ 1988. aastal oli Eestis 48 kutsekeskkooli, kus õpetati 121 erialal.

Nõukogude haridussüsteemi demokraatlikkuse tõenduseks peeti keskhariduse massilisust ja vastavate õppimisvõimaluste rohkust. Selles osas oli tõesti edasiminek, mis ei küündinud küll näiteks USA ja Jaapani vastavate näitajateni. ${ }^{47}$ Hariduse demokraatlikkuse vastandmõiste on hariduse sotsiaalne determineeritus või seisuslikkus. Hariduse massilisus ja isegi kättesaadavus on suhteline, koolide arvukus teeb hariduskorralduse vaid näiliselt demokraatlikuks, mida kinnitab Nõukogude Eesti kutsekeskkoolide kogemus. Et 1970. aastatel toimunud keskhariduse ekspansiooniga ei kaasnenud kõrgkooli vastuvõtu olulist laienemist, halvenesid keskhariduse saanute kõrgkooli astumise võimalused. Üleminek massilisele keskharidusele kindlustas selle küll kõigile noortele, olenemata nende sotsiaalsest päritolust, kuid pääs kõrgkooli jäi madalama sotsiaalse päritoluga noortele, kes olid õppinud kutsekeskkoolis või tehnikumis, tunduvalt kitsamaks. Seega ei toonud massiline keskharidus kaasa sotsiaalse päritolu mõju vähenemist noorte haridustasemele, vaid vastupidi, see isegi suurenes. ${ }^{48}$ Taasiseseisvumise järel on hariduse demokratiseerumise näitajaks toodud fakt, et märkimisväärse osa (1994/95. õppeaastal veerandi) kõrgkooli sisseastunutest moodustavad elukutset andva õppeasutuse lõpetanud. Vastavalt on siis vähenenud gümnaasiumilõpetanute osatähtsus. ${ }^{49}$ Üliõpilaskonnas on nüüd noorsoo erinevad ringkonnad võrdsemalt esindatud. Kokkuvõttes oli 1960. aastate keskpaigaks Eestis jõutud selleni, et valdav osa kooliealistest noortest käis koolis. See oli märkimisväärne saavutus, kuigi eeskätt kvantitatiivne. Kvantiteedi ja kvaliteedi harmooniline arendamine nõudnuks suuremat hariduse väärtustamist ja finantseerimist.

45 Hinno, K. Bildung und Sozialstruktur. Das Fallbeispiel Estland. Marburg, 2004, 27.

46 Sõjajärgse põlvkonna elutee ja seda kujundavad faktorid. Toim M. Titma. Tartu, 2001, 76. Keskhariduse tüübi valik sõltus ema haridustasemest ja isa sotsiaalsest seisundist. Noortest, kelle emal oli kõrgharidus, jätkas õpinguid keskkoolis $85 \%$ ja vaid $5 \%$ neist läks kutsekeskkooli. Algharidusega ema puhul ulatus kutsekeskkoolis õpinguid jätkanute protsent 42-ni. Kui isa oli kõrgharidusega juht, läks lastest $10 \%$ kutsekeskkooli; kui isa oli tööstustööline, siis $28 \%$ : Helemäe, J., Saar, E., Vöörmann, R. Kas haridusse tasus investeerida?, 65, 67.

Rohlen, T. P. Japan's High Schools. Berkeley; Los Angeles; London, University of California Press, 1983, 2-3.

48 Helemäe, J., Saar, E. Eesti haridussüsteem 20. sajandi teisel poolel, 87-88.

49 Haridus. - Eesti inimarengu aruanne 1996, 17. 


\section{KÕRGHARIDUS VAJAB UUT STRATEEGIAT JA ORIENTIIRI}

Kõrgkoolide ümberkorraldamise kavandas 1940. aasta augustis Eesti NSV Hariduse RK ja selle kiitis heaks NSV Liidu Kõrgemate Koolide Komitee. Vallandati õppejõude, Tartu ülikoolis likvideeriti usuteaduskond, majandusteaduskond aga viidi Tallinna Tehnikaülikooli (viimane nimetati märtsis 1941 Tallinna Polütehniliseks Instituudiks). Loodi marksismi-leninismi aluste kateedrid, ainesüsteemilt mindi kursuste süsteemile. Loengutest osavõtt tehti kohustuslikuks ja likvideeriti üliõpilasorganisatsioonid. Asuti kujundama uuele võimule sobivat üliõpilaskonna koosseisu: sisseastujatelt nõuti tõendit sotsiaalse päritolu ja vanemate varandusliku olukorra kohta. Ülikool kaotas teaduskraadide andmise õiguse, tehti plaane arstiteaduskonna eraldamiseks iseseisvaks instituudiks. Nii püüti lämmatada Tartu vaimu ja õpetamise ning teadustöö vabadus kadus hoopis. Nagu keskkoolis kaotati ka kõrgkoolis õppemaks, kuid mitte nendel, kelle vanemad said mittetöist tulu. NSV Liidus olid keskkool ja kõrgkool maksulised kuni 1956/57. õppeaastani. Nagu kutse- ja keskerikoolid käisid kõrgkoolidki ühe ametkonna käest teise kätte.

Kõrgkoolide statsionaarsetesse osakondadesse pääsemisel oli nõukogude noortel ees rohkem kitsendusi ning tõkkeid kui USA-s ja teistes arenenud tööstusmaades. Prantsusmaal näiteks loeti üliõpilaste valikulist vastuvõtmist riiklikesse ülikoolidesse põhiseadusevastaseks. Nn sotsialismimaad noorte niisugust õigust ei tunnustanud. ${ }^{50}$ Nõukogude kõrgharidussüsteemi iseloomustas liialdamine kaugja õhtuse õppega. Stalini eluajal puudus veel Eesti kõrgkoolides ja tehnikumides efektiivne kaugõppekorraldus. Eriti rõhuti õppimisele töö kõrvalt 1950. aastate lõpust alates. Kaugõppe arendamist kõrgkoolide põhiliseks õppetöövormiks võeti riikliku ülesandena. Kaug- ja õhtuste osakondade üliõpilastele tehti soodustusi, sh pikkade õppepuhkuste näol. Unistati, et kaugemas perspektiivis sulab statsionaarne õppimine kaugõppega kokku üheks õppevormiks. ${ }^{51}$ Õigesti rõhutati, et teaduse ja praktika areng nõuab, et üha enam haritlasi omandaks kõrghariduse rohkem kui ühel erialal või valdkonnas. ${ }^{52}$ Ometi ei muutunud see Nõukogude Liidus ulatuslikuks nähtuseks. Ehkki saavutati muljetavaldavaid kvantitatiivseid näitajaid, ei pääsenud Nõukogude Liidu kõrgkoolidesse kunagi kõik keskharidust omavad soovijad. Selekteeriti mitmete tunnuste alusel: sõjajärgsel ajal sotsiaalne päritolu ja ankeedi puhtus, hiljem tööstaaži olemasolu ja teenimine Nõukogude armees. Keskkoolilõpetanutelt nõuti asutuste, ettevõtete ja ühiskondlike organisatsioonide (ametiühing, komsomol) soovitust, eeliseid andis töölisnoorte ettevalmistusosakonna lõpetamine jne. Üliõpilaskandidaadi teadmised ja võimed ei olnud sellel skaalal ainumääravad ja ka mitte kõige mõjuvamad. Kõrgkoolidesse vastuvõtu poliitika jäi ka Stalini-järgsetel aastatel kummaliseks, demokraatlikule arusaamale vastuvõetamatuks, kus endiselt tehti eelistusi sotsiaalsete näitajate põhjal.

50 Hobsbawm, E. Äärmuste ajastu. Lühike 20. sajand 1914-1991. Tallinn, Varrak, 2002, 330.

51 Pesti, M. Kõrgem haridus uutel teedel. - Eesti Kommunist, 1960, 5, 54-55.

52 Samas, 55. 
Kõrgkooli õppeajast hõlmas märgatava osa ideoloogiline kasvatustöö, spetsialistide üldhumanitaarne haritus ja teadmised juhtimisest, psühholoogiast ning eetikast jäid tagasihoidlikeks. Kasvatustöö oli üle politiseeritud. Tehnoloogiline revolutsioon nõudis aga töötajatelt üha enam vastutustunnet ja inimlikkust.

Sõja järel oli Eestis vähem üliõpilasi kui sõja eel. Põhjused olid vaid osaliselt objektiivsed, s.o hävinguga seotud. Olulist osa mängis ka nõukogude haritlaspoliitika oma ebademokraatliku selektsiooni ja üliõpilaste ning õppejõudude tagakiusamisega. Päevastes osakondades kasvas üliõpilaskond suhteliselt aeglaselt: 1945. aastal 3 577, 1951. aastal 7 007, 1961. aastal 8 074, 1971. aastal 12 491, 1981. aastal 16005 ja 1985. aastal $14145 .{ }^{53}$ Tsentralismi varisemise aastatel suurenes päevaste osakondade üliõpilaste arv (1990. aastal 17 172), mis taasiseseisvunud riigis omandas enneolematu tempo. 1960. aastatel, mis maailmas oli kõrghariduse kiire kasvu kümnend, jäi Eestis üliõpilaste arvu kasv üleliidulisele keskmisele alla: Eestis kasvas päevaüliõpilaste arv 8 074-lt (1961) 12 491-le (1971), Nõukogude Liidus aga 2396 000-lt (1960/61) 4581 000-le (1970/71). ${ }^{54}$ Ülikoolide kasv ei olnud 1960.-1970. aastatel sotsialismimaades nii silmatorkav kui samal ajal turumajandusega riikides. Hiinas aga likvideeris kultuurirevolutsioon sisuliselt kõrghariduse hoopis. ${ }^{55}$ 1970.-1980. aastatel jäi idablokk Läänest ikka rohkem maha. Kõrgharitlaskonna massiliseks muutumine oli probleem, millesse Nõukogude juhtkond ei suhtunud üheselt. ${ }^{56}$ Teatavasti oli ideoloogia keskseks ideeks erinevuse järkjärguline kadumine vaimse ja füüsilise töö vahel. Tegelikkus oli aga järgmine: ühelt poolt säilis füüsiline töö, milles vaimset elementi oli minimaalselt, liigagi suures ulatuses, teisalt kasvas vaimset tööd tegevate inimeste hulk. Kokkusulamist võis kohati mingil määral tõestada, kuid vähemalt sama selge oli polariseerumistendents. Kui 1970. aastatel kõnelesid parteijuhid, et insener-tehniline intelligents on Nõukogude ühiskonna kõige kiiremini kasvav kiht, siis oli selles uhkustunde kõrval ka teatud nõutust. Loomulikult püüti uue jõuga tugevdada tööliste osakaalu parteis. Samal ajal hakkas kõrgkoolidest ellusaadetavate spetsialistide hulk vähenema. Eestis olid need näitajad järgmised: 1981. aastal 3709 , 1985. aastal 3575 ja 1988. aastal 2706 lõpetanut. Väike tõus ilmnes alles kümnendi lõpul: 1989. aastal 2977 ja 1990. aastal 3129 lõpetanut. Langustendents iseloomustas ka keskerihariduskoolide lõpetanute arvu: 1983. aastal 5895 ja 1990. aastal 4747 lõpetanut. $^{57}$

\footnotetext{
Rajangu, V. Kõrgharidus, 458.

54 Coombs, P. H. The World Crisis in Education, 208.

55 Hobsbawm, E. Äärmuste ajastu, 328.
}

56 Üheks massiharitlaskonna mõiste kriteeriumiks võiks olla tööga hõivatud elanikkonna ja töötavate kõrgharitlaste suhe 10 : 1-le. Eesti haritlaskond jõudis sellesse staadiumi 1970. aastatel: 1959. a üks kõrgharitlane 28, 1970. a 14, 1979. a 9 ja 1989. a 7 töötaja kohta.

57 Andmed a-te 1945-1983 kohta vt Eesti NSV rahvamajandus 1983. aastal. Tallinn, 1984, 234, 238; a-te 1985-1988 kohta vt Eesti NSV rahvamajandus 1988. aastal. Statistika aastaraamat. Tallinn, 1989, 318, 321; a-te 1989 ja 1990 kohta vt Statistika aastaraamat 1991. Tallinn, 1991, 161, 164; 1984. a kohta vt Eesti NSV rahvamajandus 1985. aastal. Statistika aastaraamat. Tallinn, 1986, 250, 253. 
Nõukogude Liidu majandus arenes aastaid ekstensiivselt, mistõttu tehnoloogiline mahajäämus Läänest paistis vähem silma. 1960. aastateks olid vabad ressursid otsakorral, edasine areng nõudis majandusliku efektiivsuse suurendamist, mis eeldas igakülgset tehnoloogilist protsessi. ${ }^{58}$ Siin takerdus Nõukogude Liit aga oma vastuoludesse. Sama teed läks ka haridus, kus areng laiuti ei taganud enam edasiminekut. Kõrghariduse andmist asutigi piirama: vähendati õhtuste osakondade ja kaugõppeüliõpilaste arvu. Näiteks õppis Eesti kõrgkoolides kaugõppes 1965. aastal 8 934, 1985. aastal aga 7576 inimest. ${ }^{59}$ Analüüs näitas, et keskharidusejärgset haridust ei oldud Eestis arendatud kooskõlas hõive struktuuriga. Kõrgharitlased töötasid sageli madalamat haridust nõudval kohal: 1985. aastal töötas tööliskohal 4,4\% Eesti kõrgharidusega spetsialistidest ja 1989. aastal 5,5\%. Keskeriharidusega spetsialistide puhul olid vastavad näitajad $27,1 \%$ ja $33,6 \%$. Seda nähtust püüdis ametlik ideoloogia omapäraselt ülistada kui tõendit vaimse ja füüsilise töö kokkukasvamisest kommunismi ehitamise käigus. Ometi pidas osa nõukogude sotsioloogidest seda juba 1980. aastatel mitte uhkuseks, vaid väärarenguks: "Inseneride töötamine töölistena /.../ kinnitab olemasoleva juhtimissüsteemi võimetust tagada ühiskonna sotsiaalsete ressursside efektiivset funktsioneerimist." ${ }^{\circ 0}$ Tänu sellisele poliitikale ei ilmnenud Nõukogude Eestis mitte kõrgharitlaste tööpuudus, vaid nende alahõive hariduslikus mõttes, mis põhjustas tööga rahulolematust. ${ }^{61}$ Oleks vale öelda, et kõrghariduse heaks midagi ei tehtud. Sellest kõnelevad TPI ülikoolilinnak Mustamäel, mis põhijoontes valmis 1960. aastatel, ja mitmed TRÜ õppe- ja muud hooned 1970.-1980. aastatest. Puudu jäi aga vabast vaimust ja paindlikkusest teadus- ning ülikoolipoliitikas. Haridussüsteemi, eriti kõrgharidusse, suhtus Nõukogude juhtkond üldiselt tehnokraatlikult. Sellele vaatamata iseloomustas haridust suur tehnoloogiline mahajäämus.

Kõrghariduse jätkuvast diferentseerimisest ja globaliseeruva haridusvälja mõnede moodsate algete tekkest annab tunnistust, et 1970. aastatel andsid Eesti kõrgkoolid lõpetanuid juba sellistelgi uutel erialadel nagu automatiseeritud juhtimissüsteemid ja majandusküberneetika. Ometi ei loobutud eesmärgist, et iga kõrgkooli lõpetanud spetsialist oleks saanud ka Nõukogude partokraatiat teeniva poliittöötaja väljaõppe. Kuigi pedagoogikateadlased teadsid, et arenenud maades käsitatakse professionaalsust üha laiemalt protsessina, mida ei omandata mõne aastaga kõrgkoolis, vaid ka pidevalt tööelus, jäi selle praktiline elluviimine puudulikuks ja sageli primitiivseks. Individuaalõppe rakendamine nõukogude kõrgkoolis oli liialt tagasihoidlik. See algas hiljem ja jäi Läänest kaugele maha. 20. sajandi teise poole tehniline kõrgharidus nõudis otsesidemeid tööstuse ja kogu rahvamajandusega. Sellest räägiti palju, kuid paradoksaalselt ei vastanud nende efektiivsus kaugeltki aja nõuetele. ${ }^{62}$ Samas olid kõrgkoolide õppejõududel, kõnelemata kesk-

58 Köörna, A. Prometheuse teener. Tartu, 2002, 68-69.

59 Rajangu, V. Kõrgharidus, 458.

60 Заславская Т. И. Социетальная трансформация российского общества. Деятельностно структурная концепция. Москва, 2003, 61.

61 Teder, J. Teel turumajandusse - kellega?, 2. - Tehnika ja Tootmine, 1990, 11, 7.

62 Tamm, B. Teaduslik-tehnilisest progressist ja kõrgharidusest. - Eesti Kommunist, 1988, 9, 59. 
või kutsekoolide õpetajatest, enese välismaal täiendamise võimalused ülinapid, paljudel aga puudusid üldse. Nõukogude kõrgharidus vajas põhjalikku ümberkorraldamist, viimaks seda vastavusse üldise keskhariduse ja massiharitlaskonna kujunemise ajajärgu tingimustega.

\section{PÄÄSETEE OTSIMINE KRIISIST}

Eesti intellektuaalid mõistsid, et hariduskriis oli käes. Impeeriumi viimasteks kümnenditeks oli kool akadeemik Heino Liimetsa arvates ummikus, sest ei suutnud ühiskondlike muutustega kaasas käia ja oli arengust maha jäänud. ${ }^{63}$ Kasutades P. H. Coombsi hariduskriisi termineid, süvenesid kohandumisraskused ja lõhe laienes. Tänapäeva Venemaa autorid tunnistavad, et Nõukogude hariduskorraldust tabas sügav kriis, kuid nad seostavad seda enamasti vaid 1980. aastatega ${ }^{64}$ On ka neid, kes jagavad Nõukogude haridusloo kahte põhietappi: tõus kuni 1950. aastate lõpuni ja allakäik 1960. aastate algusest, mis jõudis 1980. aastatel ilmselgesse kriisi. ${ }^{65}$ Vene autorid kirjutavad impeeriumist üldiselt ja tavaliselt ei arvesta okupeeritud Baltimaade traagilist eriolukorda.

1980. aastate teisel poolel lõdvenes NSV Liidu kontroll Eesti hariduselu üle. Kui perspektiivis hakkas terendama vabam tulevik, mõistsid mõtlevad pedagoogid, et tuleb kasvatada inimest, kes tahab hoolt kanda oma riigi käekäigu eest, kes oskab olla demokraatliku ühiskonna vastutustundlik kodanik. Ühtlasi leiti, et noor inimene peab suutma vastutada ka oma isikliku arengu ja omaenese saatuse eest. Vaba elukorraldus ja liberaalne turumajandus nõuab ka iseseisvalt toimivat kooli. Niisuguseid mõtteid väljendati pedagoogide nõupidamistel ja pressis. ${ }^{66}$

Kümnendi lõpul alustati hariduse detsentraliseerimist, otsustamisõigust anti kohalikele haridusorganitele ja koolijuhtidele. Uuendati hariduse sisu ja venekeelset kooli püüti Eestile lähendada. Vabariigi suveräänsuse ja IME taotlemise aastatel hakati otsima võimalusi haridussüsteemi muutmiseks Eesti-keskseks ja iseseisvaks, eriti kõrgkooli radikaalseks ümberkorraldamiseks. Teadvustati, et suurriiklik haridusideoloogia, mis kõlavatest sõnadest hoolimata alahindas reainimese arendamist, väikesele rahvale ei sobi. 1987.-1988. aastal toodi avalikkuse ette hariduse uued eesmärgid ja ideaalid. Aktuaalseks põhiteesiks kujunes, et mitte mingisugused kõrgemad riiklikud huvid ei õigusta inimese arenguvabaduse piiramist. Haridus pidi saama rahvuskultuuri taimelavaks, samaaegselt õpetama erinevate kultuuridega suhteid looma. Uuendamise peasuundadeks peeti demokratiseerimist, humaniseerimist ja hariduse väärtustamist. Nagu eestikeelne nii pidi ka venekeelne keskharidus hõlmama 12 õppeaastat. Levis mõte, et kool tuleks vabastada

63 Akadeemik Heino Liimetsa lugu. - Kultuur ja Elu, 1988, 1, 31.

64 Богуславский М. Образование. - Большая Российская Энциклопедия. Россия. Москва, 2004, 683.

65 Капранова В. А. Становление и развитие предуниверситетской школы в Европе. Минск, 1996, 110.

66 Roots, H. Isiksuse demokratiseerimine. - Nõukogude Kool, 1988, 1, 24. 
ühiskonna diktaadi alt ja lõpetada riiklik monopol haridusele, isegi lahutada kool riigist, nagu omal ajal eraldati kirik koolist. Kool tuli vabastada poliitilisest survest, prioriteet anda üldinimlikele väärtustele. Kõrgkoolidele tuli anda autonoomia ja võtta suund laiema profiiliga spetsialistide koolitamisele. Kiideti heaks idee kõrgkoolide regionaalsete filiaalide avamisest. ${ }^{67}$

Uus vaatekoht (ehkki vanas, marksistlikus mõistesüsteemis) oli, et haridust ei käsitata pealisehitise, vaid baasina. Seega nõuti loobumist hariduse ainelisest diskrimineerimisest ja hariduse finantseerimisest nn jääkmeetodil. ${ }^{68}$ Vahendid kooli muutmiseks innovatsioonimehhanismiks pidi andma tööstuse ekstensiivarendamise lõpetamine Eestis ja vabanenud summade suunamine haridusse ja teadusse. ${ }^{69}$ Kõrgkooli põhiprobleemina nähti nüüd õpetuse kvaliteeti; kinnitati, et suveräänses vabariigis ei vajata spetsialistide hulgalist vorpimist. Kvaliteedi pidi tagama kõrgkoolide ning teadusasutuste senisest tihedam koostöö, väljumine rahvusvahelisest isolatsioonist, välismaa külalisõppejõudude kasutamine ja üliõpilaste ning aspirantide suunamine välismaale. ${ }^{70}$ Õpetajad ja õpilased (resp üliõpilased) hakkasid kord iseseisvust omanud ja selle taastamist taotlevat rahvast alandavat Nõukogude haridussüsteemi omaalgatuslikult lammutama juba enne süsteemi täieliku halvatuse saabumist. Läänega koostööle orienteeritud hariduslik suund jõudis 1980. aastate lõpul alternatiivsete institutsioonide loomiseni, nagu Estonian Business School.

\section{KOKKUVÕTE}

Eesti NSV suveräänsus osutus ka hariduse vallas juba 1940.-1941. aastal fiktsiooniks. Koolisüsteemi vaadeldi NLKP eesmärkidest lähtuvalt kui nõukoguliku mõtteviisi kujundajat ja kuuleka ning vähenõudliku tööjõu koolitajat. Hariduselu juhtnöörid esitas NLKP oma kongressidel ja pleenumitel, millele järgnesid üleliidulised ja nende alusel vabariiklikud haridusseadused ning määrused. EKP, kelle ülesanne oli organiseerida NLKP otsuste täitmist Eesti NSV-s, juhtis ja kontrollis kultuuri, sh haridust ja teadust, oma vastavate osakondade, samuti riiklike haridusorganite ja õppeasutuste parteiorganisatsioonide kaudu. Osa koole ja kõrgkoole viidi otse üleliidulisse alluvusse. Seega ei saa rääkida kogu Eesti NSV haridussüsteemi kohalikust juhtimisest. Kuid selleski osas, kus kohalikku juhtimist lubati, oli see alati allutatud üleliidulistele institutsioonidele. Õpetaja tööd hinnati ühiskondliku aktiivsuse ja õppeedukuse protsendi alusel, mis viis õpilaste õpimotivatsiooni langemisele. Impeeriumi lõpu eel näitas sotsioloogiline uuring, et õpetaja kui loovisiksus oli kaotanud oma koha ühiskonnas. ${ }^{71}$ Oppetöös pandi liialt rõhku faktidele. Vene keelt õpetati eestlastele väidetavalt vabatahtlikkuse alu-

67 Rajangu, V. Entwicklungswege des Bildungswesens in Estland. Eesti ühiskonna arengu sotsiaalsed ja õiguslikud aspektid. - Tallinna Tehnikaülikooli Toimetised, 1993, 735, 57-59.

Ruus, V., Neudorf, R. Eesti haridussüsteem statistikapeeglis. Tallinn, 1995, 43.

69 Virkus, R. Uuenev kõrgkool: hoovõtult tegudele. - Eesti Kommunist, 1989, 10, 45.

70 Samas, 43-44.

71 Kirch, A., Kirch, M. Eesti ja vene õpetajate kultuurihuvidest ja rahvushoiakutest. - Nõukogude Kool, 1989, 10, 11. 
sel, kuid sundus ja kontroll oli selle õpetamise üle suurem kui üheski teises aines. ${ }^{72}$ NLKP asetas erilist rõhku töökasvatusele ja töötahte õhutamisele, mida mõisteti primitiivselt. Vaja olnuks aga enam arendada elukestvat õppimist, mõtlemisvõimet ning loovust ja anda vabadust.

Hariduse demokratiseerimine osutus sõnakõlksuks. Juba esimesed okupatsioonikuud tõid kaasa jõhkra sotsiaalse vahetegemise, mis oli absoluutne (kodanliku ühiskonna nn klassikoolis oli kehvast kodust lapsel vähemalt lootust abirahale või õppemaksust vabastamisele). Arendati kutsekoolide võrku, mis oli töölisnoorte hariduslik umbtänav. Ning kui lõpuks oli keskharidus massiliseks muutunud, hakkas kõrghariduseni pääsejate selektsioon toimima lihtsalt keskkoolilõpetanute tasemel, s.o nn pudelikaelana toimis senisest kõrgem haridustase. ${ }^{73}$

Tänu Eesti kooli ja õpetajaskonna traditsioonidele, samuti loovharitlaste ning haridusjuhtide (eeskätt haridusminister Ferdinand Eiseni) pingutustele õnnestus siiski säilitada eestikeelses koolis kohalikku ja rahvuslikku omapära. See väljendus üldhariduskooli pikemas õppeajas (1958-1964/65 oli kogu NSV Liidus 11-aastane keskkool), koorilaulutraditsiooni edasikandmises ja õpilaste massilises osavõtus rahvuskultuuriüritustest, mida võib vaadelda õpilaste ja õpetajate passiivse vastupanuna, võib-olla ka selleaegse kooli ühe varjatud funktsiooni väljendusena.

Nii stalinismi ajal kui ka 1970. aastate lõpu uusstalinistliku surve tingimustes jäi eesti keel ja kirjandus üheks kõige kesksemaks õppeaineks, emakeelset haridust pidasid nii õpilased kui lapsevanemad eestlaste loomulikuks õiguseks. Haridussüsteemi lausvenestamist 19. sajandi lõpu vaimus ei korratud, kuid seda püüti teostada järk-järgult. 1970.-1980. aastatel üritati vormida ühtset nõukogude rahvast ühe keele, s.o vene keele baasil. Keeleline agressioon tugevnes. Eesti keelt tõrjuti paljudes keskeriõppeasutustes ja üritati piirata eestikeelset kõrgharidust. Eestlased tajusid selgesti rahvuskultuurile tõeliselt kriitilise etapi lähenemist, kui kõrg- ja keskkool taheti valdavalt venekeelseks muuta. Oli näha, et impeeriumi valitsevad ringkonnad valisid 1970. aastail ummikust väljapääsemise vahendiks taas ägeda keelelise ja kultuurilise venestamise. Intelligentsi aatelisema osa ja õppiva noorsoo vastus sellele olid dissidentlus, õpilasrahutused ja 40 kiri, milles on õigusega nähtud stagnatsiooniperioodi lõpu algust.

1950.-1960. aastatel oli maailmas üldtunnustatud hariduse sirgjoonelise, piirideta arengu kontseptsioon. See põhines usul, et haritud inimeste pidevalt kasvav rakendamine on majanduskasvu aluseks, et arenevad majandused suudavad tööd anda kõigile eriharidusega inimestele, kui tahes palju neid ka koolitatakse. Seejuures loodeti liialt minevikust pärit haridussüsteemile, hinnati üle selle suutlikkust teaduse ja tehnika kiirarengule põhineva majanduse ja muude eluvaldkondade nõudmistega sammu pidada. ${ }^{74}$ Teadus- ja tehnikarevolutsioon oli kogu maailmas tuntud mõiste, kuid pedagoogikarevolutsioonist ei julgetud õieti kõneldagi. Sel-

72 Eisen, F. Kakskümmend aastat Tõnismäel, 972.

73 Helemäe, J., Saar, E. Eesti haridussüsteem 20. sajandi teisel poolel: kohortide võimalused ja valikud, 88.

74 Coombs, P. H. The World Crisis in Education, 172-173. 
gus, et spetsialistide ettevalmistamise optimaalset plaani on väga keeruline välja töötada. Ka rangelt tsentraliseeritud ja plaanimajandusega Nõukogude Liit oli majandusarengu ja tulevaste haridusvajaduste kooskõlastamisel raskustes nagu paljud teisedki riigid, kusjuures siinsed probleemid sarnanesid paljuski arengumaade omadega. Tunti uhkust inseneride massilise koolitamise üle, kuid maha jäädi majandus- ja juhtimisteadlaste koolitamisel - nendel aladel õppis USA-s kaks korda rohkem üliõpilasi kui NSV Liidus. ${ }^{75}$

Nagu majanduslikus ja sõjalises konkurentsis nii rauges NSV Liidu jaks ka hariduse võidujooksus. Viimase osas selgus see sajandi kolmanda veerandi lõpuks. UNESCO riikides hinnati noorsoo haridustaset, informeeritust, võõrkeelte oskust, lugemust jne intellektuaalsuskoefitsiendi põhjal. 1950. aastate algul paigutati NSV Liit selle järgi kolmandale, 1960. aastatel koguni teisele kohale. 1980. aastate keskpaigaks olid aga impeeriumist nii noorsoo kui kogu elanikkonna intellektuaalsuskoefitsiendi osas möödunud kümned riigid. ${ }^{76}$

Kooli arengut pidurdas Nõukogude Liidu isoleeritus ülejäänud maailmast. Õppetöö efektiivsust vähendas ka puudulik varustatus moodsa infotehnikaga, mis osalt tulenes rahanappusest ja vastava kodumaise toodangu puudumisest, kuid ka riigivõimu kartusest oma alamate ees. Ilmnes juhtkonna teadlik või vähemalt alateadlik hirm suletud süsteemidele hukatusliku elektroonilise infoajastu ees. Ses suhtes on iseloomulik, et igasugust kopeerimis- ja paljundustehnikat lubati soetada rangete piirangutega, isegi tavalised trükimasinad olid eriarvel. Infonälg oli üks Nõukogude hariduskriisi silmapaistev erijoon.

Haridussüsteem pidi kaasa aitama ühiskonna sotsiaalse homogeensuse suurenemisele. Tegelikult osutus see protsess Nõukogude Liidus nagu paljudes maades oodatust palju keerulisemaks. Hoolimata partei haritlaspoliitilistest taotlustest kujundada intelligents peamiselt tööliste ja kolhoositalurahva baasil, oli ka Nõukogude Liidu haridussüsteemi kodeeritud, et see andis suuremad võimalused lapsele, kellesse vanemad olid sisendanud hariduse väärtustamise ja õppimismotivatsiooni. ${ }^{77}$ Läbi poliitilise sõela, võttes arvesse päritolu ning rahvust, pääses mõnedesse sõjakoolidesse ja diplomaatilisele ning parteitööle ettevalmistavatesse õppeasutustesse. P. H. Coombs väitis 1985. aastal, et Nõukogude Liidu hinnatuimad ülikoolid Moskvas ja Leningradis on nõukogude kesk- ja kõrgema klassi noorte (akadeemikute, kindralite, komissaride, parteiesimeeste ning rahvakunstnike laste) kasvulava, kus nad valmistuvad juhtivale kohale tõusmiseks. ${ }^{78}$

Ometi tõusis elanikkonna haridustase. 1939. aastal tuli Eestis 1000 inimese kohta (alates 10. eluaastast) neid, kellel oli kõrg-, kesk- või mittetäielik keskharidus, 161 (NSV Liidus 108), 1979. aastal aga 630 (NSV Liidus 638). 1970. aastal oli keskeri-, lõpetamata kõrg- ja kõrgharidusega 20,3\%, 1979. aastal 29,4\% tööta-

75 Миронов В. Б. Век образования. Москва, 1990, 162.

76 Samas, 145-146. Riikide statistika erinevuste tõttu võib UNESCO paremusjärjestustes ette tulla ka üsna kummalisi eksitusi. Selle kohta vt Teder, J. Teel turumajandusse - kellega?, 2. - Tehnika ja Tootmine, 1990, 11, 7-8.

77 Vrdl Coombs, P. H. The World Crisis in Education, 212.

78 Samas, 216. 
vast rahvastikust. 1989. aasta rahvaloenduse järgi oli Eestis kõrgharidusega 10,7\% rahvastikust (alates 10. eluaastast) (1934. aastal 0,8\%, 1970. aastal 4,7\%). ${ }^{79}$ Formaalhariduse kvantitatiivsed näitajad olid 1991. aastal Eestis mõneski aspektis võrreldavad arenenud riikide omadega ja ületasid osaliselt Kesk-Euroopa sotsialismimaade omi. ${ }^{80}$ 1989. aastal olid Baltimaad postsekundaarse hariduse näitajate poolest Ungarist ees, kuid Soomest jäid maha. ${ }^{81} 1920 .-1930$. aastatel oli aga Eestis 100000 elaniku kohta üliõpilasi rohkem kui põhjanaabril.

1980. aastate keskpaigaks oli kirjaoskuse protsent Nõukogude Liidus jõudnud küll 100 lähedale, kuid 20. sajandi lõpul ei iseloomustanud see enam maa arengutaset sel määral kui sajandi algul. Enam kõneles tõsiasi, et üle 30\% tööstuses hõivatutest ja $70 \%$ põllumajanduses töötavatest inimestest tegi päevast päeva lihtsat käsitsitööd. ${ }^{82}$ Paraku määras just viimane näitaja - ilmselt rohkem kui ponnistused üldise keskhariduse suunal, tuumaarsenal ja kosmosetehnika - impeeriumi asendi ülemaailmsel tsivilisatsioonikaardil. Nõukogude ühiskond ei saanudki küpseks industriaalühiskonnaks. Industriaalajastu ülesanded olid veel osaliselt täitmata, seetõttu takerdus ka teaduslik-tehniline revolutsioon ja sammud infoühiskonna suunas jäid lühikesteks.

Nõukogude hariduspoliitika oli konfliktne nii isiksuse-ühiskonna kui ka keskuse-ääremaa (liiduvabariigi) tasandil. Nappis perspektiivitunnetust, liialt keskenduti oleviku vajadustele ja majanduse hetkeseisu umbsõlmedele. Kujundlikult öeldes õpetati arvelauda ajal, mil tulnuks noori harjutada töötama raalidel. Öeldu ei olegi pelgalt kujund, vaid 1960. aastate TPI majandusteaduskonna reaalsus. ${ }^{83}$ Tulemus oli, et Nõukogude süsteem ei suutnud rahuldada ei rahva ainelisi ega vaimseid vajadusi.

Kogu maailma haridus oli 20. sajandi teisel poolel teinud edusamme, eriti industriaalmaades, mille hulka kuuluvaks loeti ka Nõukogude Liit. Ehkki usalduskriis hariduse (resp haridussüsteemi) vastu andis end tunda, püsis usk hariduse jõusse endiselt. Nii oli see okupeeritud Eestiski, kus pealesunnitud ja võõrsilt valitsetavale koolikorraldusele vaatamata oli rahva haridustase ikkagi tõusnud. Samas oli nõukogude haridussüsteem üks relvi teises vallutuses, mis eestlaste ajalooteadvust ja ajaloolist mälu paratamatult mõjutas. Okupatsiooni, allasurutust põlistab aga kõige enam harimatus. Haritus, ka rõhuja kontrolli all antu, muudab allutatu ikkagi sotsiaalselt arenenumaks, seega raskemini valitsetavaks ja juhitavaks. ${ }^{84}$

Kool aitas juba oma latentse funktsiooni tõttu kaasa rahvusliku identsuse säilimisele, kujundas eesti intelligentsi uued põlvkonnad. Kasv oli muljetavaldav: paarilt tuhandelt kõrgharitlaselt 1944. aasta sügisel 142 000-ni 1989. aastal.

79 Eesti rahvastik rahvaloenduste andmetel, I. Tallinn, 1995, 176-177.

80 Harituse osaindeks, mis saadakse kirjaoskuse ja koolihõive osaindeksite põhjal, oli 1990. aastate algul Eestis 0,89, Kanadas 0,99, USA-s ja Soomes 0,98. - Eesti inimarengu aruanne 1996, 15.

81 Ruus, V., Neudorf, R. Eesti haridussüsteem statistikapeeglis, 43.

82 Заславская Т. И. Социетальная трансформация российского общества, 67, 97.

83 Mereste, U. Toimunust ja kaasaelatust, 2. Meenutusi aastaist 1964-1992. Tallinn, 2004, 38-40.

84

Заславская Т. И. Социетальная трансформация российского общества, 59. 
Nõukogude haridussüsteemi ei rehabiliteeri asjaolu, et selles õppinuid ja kasvanuid on jõudnud maailmakultuuri tippude hulka. Üliandekad inimesed leidsid sageli oma tee ka dogmadesse uppunud suletud süsteemis, kuid see ei tähenda, et neid tuleks pidada selle süsteemi produktiks. ${ }^{85}$ Eesti seisund 20. sajandi maailmas oli erakordne: iseseisvumine, tunnustamine, Rahvasteliidu liikmelisus, rahvuskultuuri ning hariduse edukas areng - ja 50 aastat suurriikide okupatsiooni. Unikaalne oli ka meie hariduslugu, kus 1940. aastate sügava languse järel näitas statistika otse haridusplahvatust ja samas ilmnes hariduskriis, mida süvendas majanduse stagnatsioon ja okupeeriva totalitaarriigi ahistav survepoliitika.

\section{TÄNUAVALDUS}

Uurimus on tehtud sihtasutuse Eesti Teadusfond rahalisel toetusel (grant nr 5095).

\section{EDUCATIONAL CRISIS IN SOVIET ESTONIA}

\section{Väino SIRK}

Interesting ideas of Philip H. Coombs and the conception of the world crisis in education were known to Soviet researchers and leaders. However, they declared that educational crisis was unthinkable in a socialist country. Yet the crisis under discussion existed and deepened from year to year. At the end of the 1950s a long period of illogical and unproductive reforms $(1958,1964,1984)$ started in the Soviet educational system. The main troubles of Soviet education were permanent financial dearth, closedness, reticence, scarcity of information, underestimation of modernisation and innovation, politisation and ideological oppression, self-praise and out-of-date technology. The decisive factor that brought failure in competition with the USA in the sphere of science and education was the lack of capital for investments into the system of higher education and science. All these shortages and shortcomings characterised schools and education in the Estonian SSR as well.

By the end of the 1930s the educational system of the Republic of Estonia had reached a level that would have enabled it to keep pace with the cultural progress of the democratic world. In June 1940 the Soviets occupied the small Baltic States, including Estonia. In the Soviet Union Estonian education was placed under Moscow's control and guided by Soviet ideology. It is no exaggeration to say that in occupied Estonia education sank into crisis already in 1940. In our opinion school and education of an annexed nation, just like its self-awareness, are always in crisis.

85 Кумбс Ф. Г. Кризис образования в современном мире. Системный анлиз, 11. 
Exclusion and inhuman repression of Estonian intellectuals (among these teachers and professors) began in 1940 and lasted during Stalin's lifetime. Despite the heavy pressure, education in Estonia continued to evolve. A solid European base in Estonian culture resisted hiddenly but tenaciously and was never entirely rooted up. However, free development of education was severely hindered.

After the death of Stalin the mindless terror ended and the loosening up of the regime took place. There was indeed a significant enlargement of secondary and university education in Estonia during the 1950s-1980s. The number of persons with a university education increased from some thousand after World War II to 142000 in 1989. Nevertheless numerous limitations and hindrances on the ground of social origin and status of parents stood in the way to university education. The overwhelming majority of university students had graduated from secondary schools of good quality, which were not accessible for everybody.

That is why the author of this paper attempts to prove that although the broadening of the school net is in principle a democratic trend, it does not guarantee automatically a democratic educational system and equal opportunities for all young people. 